\title{
Power converters for battery energy storage systems connected to medium voltage systems: a comprehensive review
}

\author{
Lucas S. Xavier ${ }^{1}$, William C. S. Amorim², Allan F. Cupertino ${ }^{1,2}$, Victor F. Mendes ${ }^{1}$, Wallace C. do Boaventura ${ }^{1}$ and \\ Heverton A. Pereira ${ }^{3^{*}}$ (D)
}

\begin{abstract}
Recent works have highlighted the growth of battery energy storage system (BESS) in the electrical system. In the scenario of high penetration level of renewable energy in the distributed generation, BESS plays a key role in the effort to combine a sustainable power supply with a reliable dispatched load. Several power converter topologies can be employed to connect BESS to the grid. There is no defined and standardized solution, especially for medium voltage applications. This work aims to carry out a literature review on the main converter topologies used in BESS and highlight the main advantages and disadvantages of each one. The topologies used for each conversion stage are presented and their combinations are analyzed. In addition, the different services that BESS can carry out when connected to the distribution system are analyzed in order to demonstrate all the main contributions to the electrical systems. Finally, a case study is performed to compare and analyze the converter topologies for BESS, considering some aspects such as efficiency, power quality and number of components.
\end{abstract}

Keywords: Battery energy storage system (BESS), Power electronics, Dc/dc converter, Dc/ac converter, Transformer, Power quality, Energy storage services

\section{Introduction}

Battery energy storage system (BESS) have been used for some decades in isolated areas, especially in order to supply energy or meet some service demand [1]. There has been a revolution inelectricity generation. Today, solar and wind electricity generation, among other alternatives, account for a significant part of the electric power generation matrix all around the world. However, in this scenario of high level of renewable energy, BESS plays a key role in the efforts to combine a sustainable energy source with a reliable dispatched load and mitigates the impacts of the intermittent sources [2]. Therefore, the installation of BESS has increased throughout the world in recent years. Despite their benefits, the implementation of such systems faces considerable challenges [3].

The nominal voltage of the electrochemical cells is much lower than the connection voltage of the energy

\footnotetext{
*Correspondence: heverton.pereira@ufv.br

${ }^{3}$ Department of Electrical Engineering, Federal University of Viçosa, Av. P. H. Rolfs s/n, 36570-900, Vicosa, MG, Brazil

Full list of author information is available at the end of the article
}

storage applications used in the electrical system. For example, the rated voltage of a lithium battery cell ranges between 3 and $4 \mathrm{~V} /$ cell [3], while the BESS are typically connected to the medium voltage (MV) grid, for example $11 \mathrm{kV}$ or $13.8 \mathrm{kV}$. The connection of these systems in MV grids can contribute with various services, such as peak shaving, time shifting and spinning reserve $[4,5]$. Therefore, it is common to connect several cells in series to form a bank of batteries that is capable of delivering a minimum recommended voltage on the dclink. In several applications, this voltage is usually $600 \mathrm{~V}$, which is converted into ac for the grid connection through an inverter. Furthermore, a controllable dc-link voltage can be achieved by inserting a dc/dc stage, between the battery bank and the dc-link. Under such conditions, it is possible to increase the degree of freedom to control the battery state of charge (SOC). The $\mathrm{dc} / \mathrm{dc}$ converters also allow using less batteries in series, since the converters can boost the voltages to the grid connection [6]. It is worth mentioning that the dc/dc converter

(c) The Author(s). 2019 Open Access This article is distributed under the terms of the Creative Commons Attribution 4.0 International License (http://creativecommons.org/licenses/by/4.0/), which permits unrestricted use, distribution, and reproduction in any medium, provided you give appropriate credit to the original author(s) and the source, provide a link to the Creative Commons license, and indicate if changes were made. The Creative Commons Public Domain Dedication waiver (http://creativecommons.org/publicdomain/zero/1.0/) applies to the data made available in this article, unless otherwise stated. 


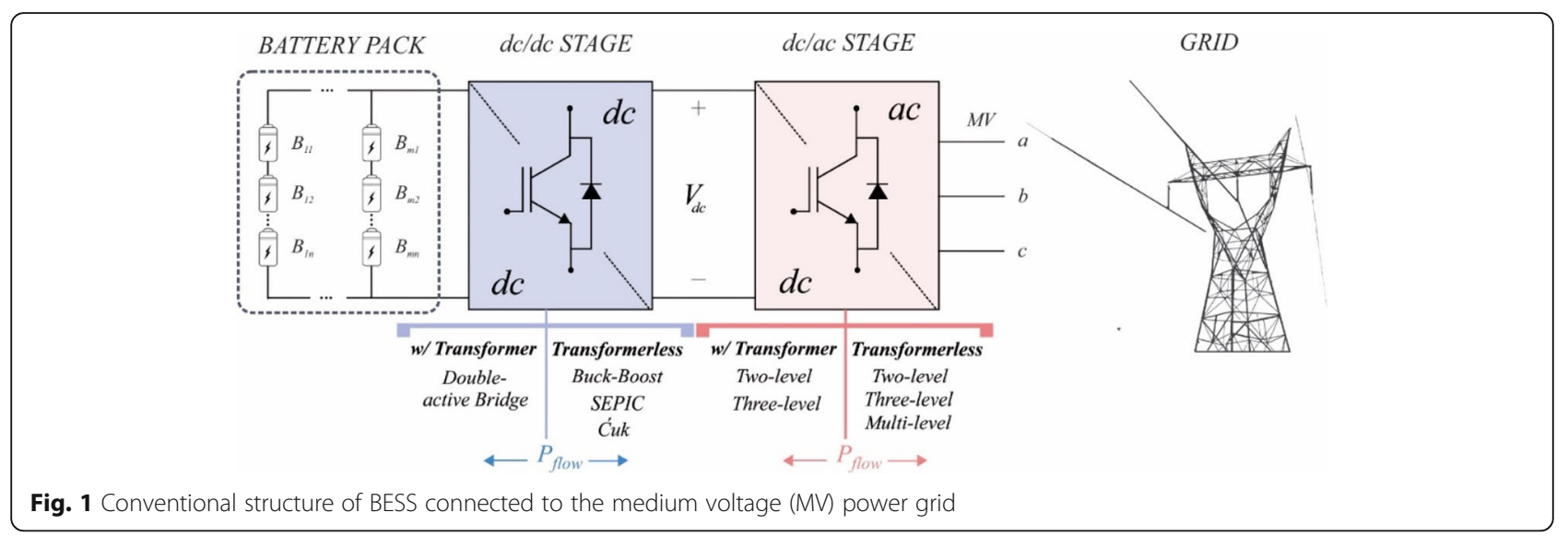

must be bidirectional to ensure the power flow of charge and discharge of the batteries $[7,8]$.

In this sense, the general structure of a BESS connected to the MV grid is shown in Fig. 1. This system is composed of the battery pack, dc/dc stage and dc/ac stage. The converter topologies in each stage are classified in topologies with transformer or transformerless. If low voltage switches are employed in the dc/ac stage for two or three level topologies, a step-up transformer is required to connected the BESS to the MV grid [9]. A disadvantage of these topologies is the high current on the transformer low voltage side, which can decrease their efficiency. Therefore, trends of transformerless dc/ ac converter technologies are being applied in BESS, such as two levels with serial switches and modular multilevel converter (MMC) $[9,10]$. However, a comprehensive analysis of cost-benefit, efficiency and system complexity is necessary to verify the advantages of these trends. The same idea applies to the $\mathrm{dc} / \mathrm{dc}$ stage, which can be isolated with high frequency transformers [11].

In view of the above, this paper proposes to perform a review of the main topologies of power converters involved in BESS and present a comprehensive insight into converter technologies for this application. Therefore, it aims to synthesize the main works in the literature, and reveal the advantages and disadvantages in terms of power losses, number of semiconductor devices, output current harmonic distortions, relevant number of control loops and the required sensors. Some issues, such as control strategies and converter design, will be approached for the analysis of the inherent complexities of each topology. Several works that deal with these issues will be investigated. Finally, a case study is carried out to compare and analyze the converter topologies for BESS, considering some aspects, such as efficiency, power quality and number of components.

This paper is outlined as follows. Section II presents an overview about the converter topologies commonly used in BESS. Section III describes the main control strategies for BESS. Section IV lists and discusses the main services provided by a BESS. Section V describes the case studies in order to compare different topologies to connect the BESS into the grid. The results are discussed in Section VI and the main conclusions are stated in Section VII.

\section{Converters topologies applied in bess}

In this work, the converter topologies for BESS are divided into two groups: with transformers and transformerless. This work is focused on MV applications. Thus, only three-phase topologies are addressed in the following subsections.

\section{Converter topologies with transformers}

The voltage source converter (VSC), ZSI (Z-source converter) and qZSI (quasi-Z-source converter), shown in Fig. 2, are the three traditional two-level converters for the dc/ac stage of BESS. For the grid connection, it is generally, it is used a low-pass filter in order to attenuate the injected harmonics. LC or LCL filter configurations are usually employed. The transformer $\left(T_{x}\right)$ is used to step-up the low voltage (LV) from the inverter side to the MV of the grid side $[12,13]$.

In the VSC configuration, the battery bank can be connected directly to the dc/ac stage capacitor or connected through the $\mathrm{dc} / \mathrm{dc}$ stage. The disadvantage of this topology is the possibility of operating only as a buck converter. Therefore, the output voltage must be lower than the dc voltage. In addition, the upper and lower switches of each phase-leg cannot be activated simultaneously. Thus, a dead time between the opening and closing of the switches must be implemented, which distorts the output waveform.

ZSI and qZSI were designed to overcome these disadvantages inherent of the VSC topology [14, 15]. Basically, these converters can operate in boost mode, because of the additional network with capacitors and inductors in the dc-link. Therefore, the short-circuit state is used to 


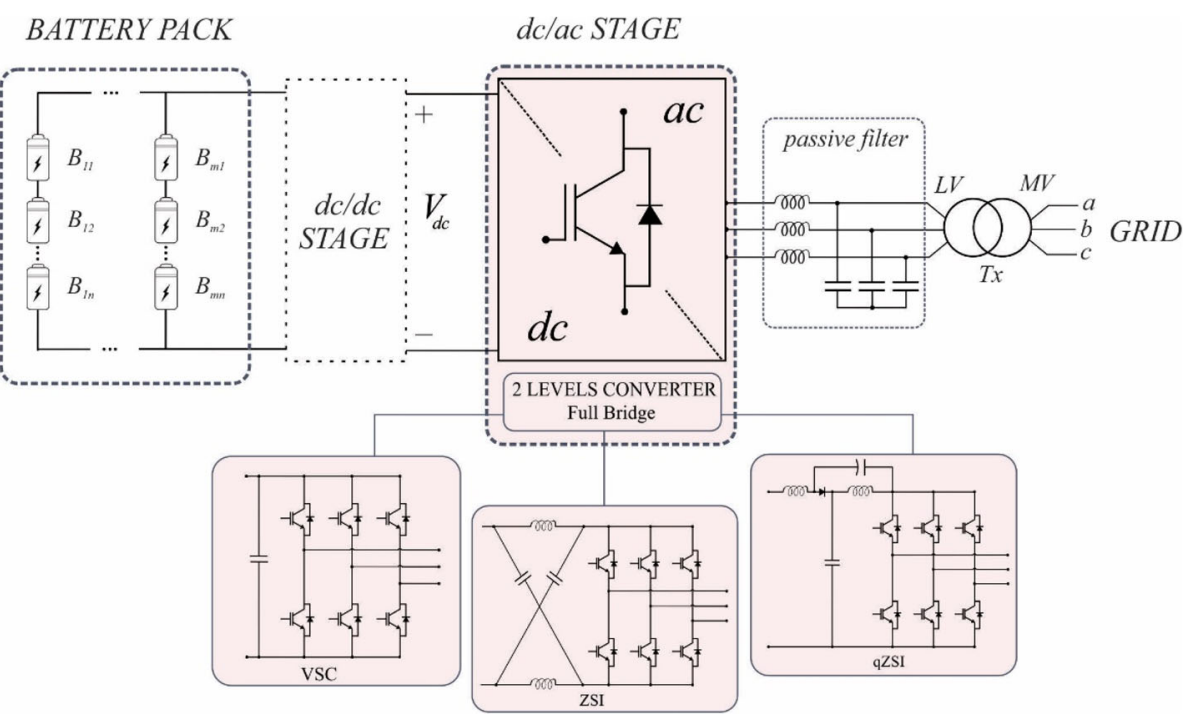

Fig. 2 Conventional topologies of two-level converters for the connection of BESS to MV grid

exchange energy between the bus elements and raise the voltage. In fact, due to these listed characteristics, many works have used the qZSI converter to integrate renewable energy sources with batteries and connect them to the grid, which prevents the use of additional dc/dc converter and reduces the number of semiconductors in the system $[16,17]$.

Despite the advantages of ZSI and qZSI, VSC is more commonly used due to its simplicity. Therefore, in this work, VSC is used to represent the two-level converters in the dc/ac stage and it is the topology simulated in the case study presented in Section IV.

For high power applications, a parallel association of BESS in power blocks is used to avoid power concentration in a single system, as shown in Fig. 3 [18]. Notice that each block is a conventional system shown in Fig. 2 . This configuration is advantageous in case of battery failure, since only one power block will be out of service [19]. Another advantage is the power blocks that can be connected at different points of the grid, and perform the services in a distributed way. These aspects are discussed in Section V. This concept of power blocks has been used for several commissioned and operating BESS around the world [20-22].

The three-level neutral-point clamped (NPC) converter is another topology widely used for BESS applications [23-25], as shown in Fig. 4. The advantage of this converter topology is the greater degree of freedom to increase the magnitude of the output voltage and improve the harmonic performance, which reduces filter requirements. This is possible due to the clamping of half of the dc-bus voltage by the NPC diodes, which reduces the voltage requirement of the power switches. The disadvantage of this topology is the more complex control and

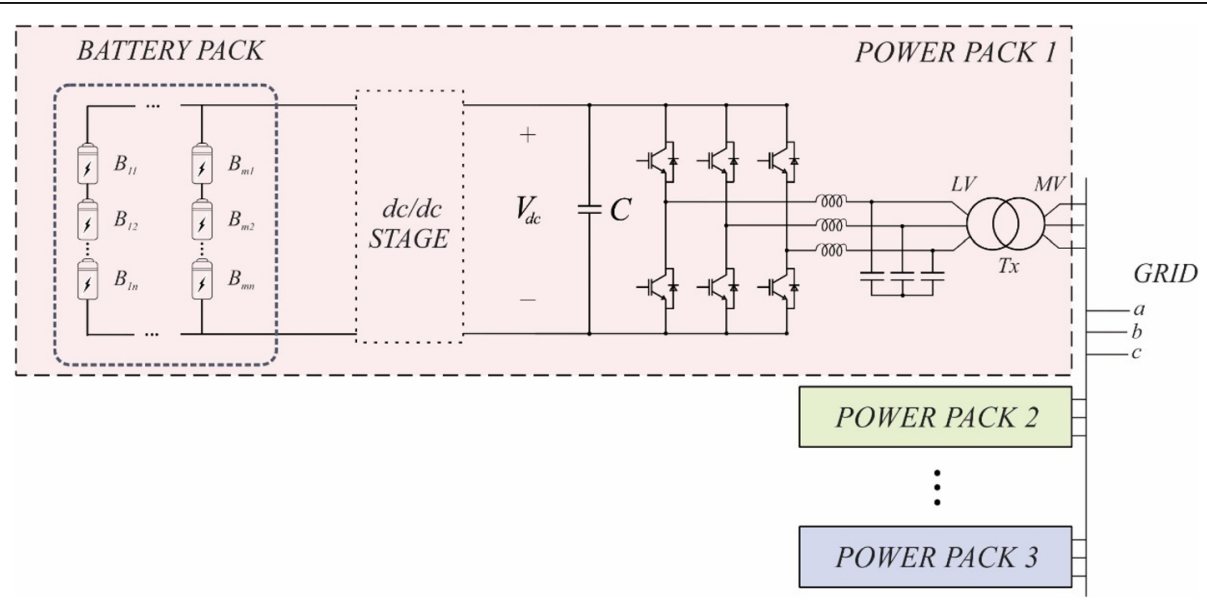

Fig. 3 Use of the power block configuration for connecting BESS to the MV grid 


\section{BATTERY PACK}

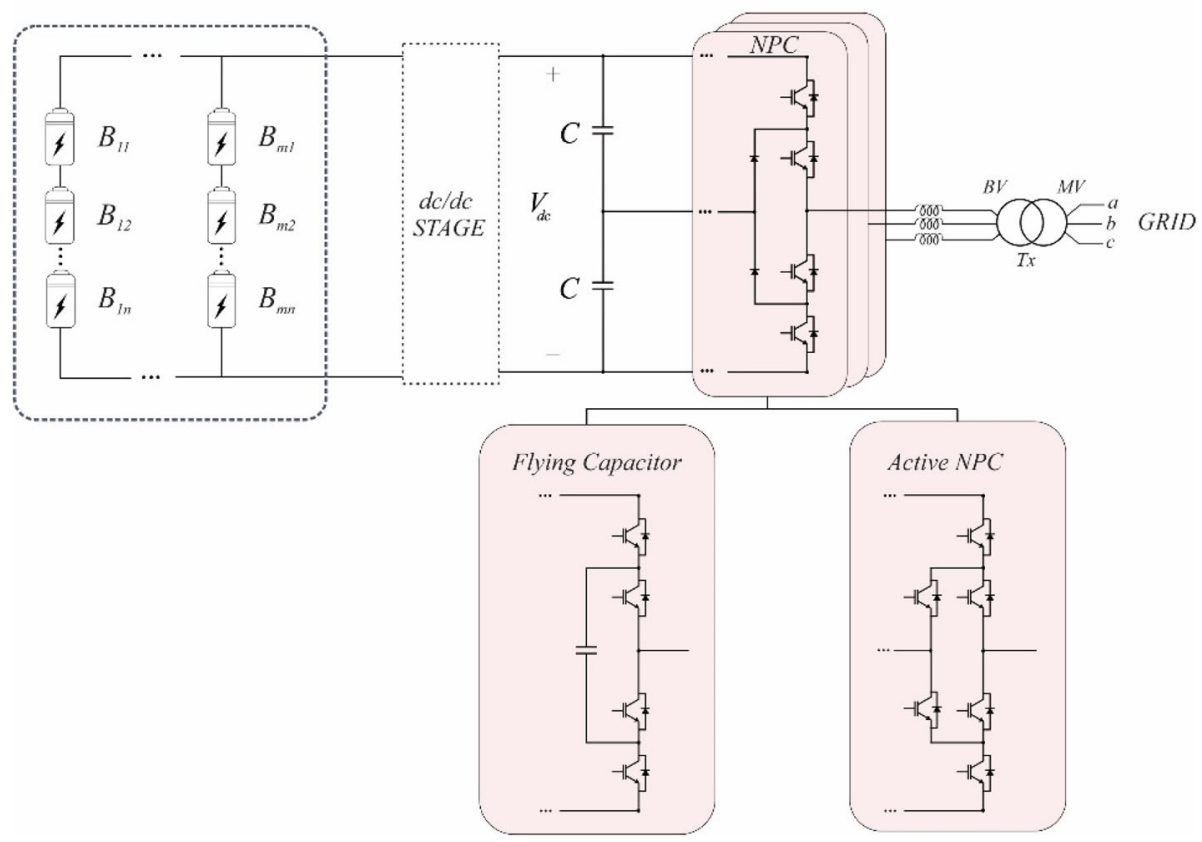

Fig. 4 Three level converter topologies

modulation techniques required in relation to the twolevel converters [26]. The $200 \mathrm{kWh}$ pilot project commissioned in Norfolk, UK, in 2011, which used ABB's DynaPeaQ solution with a NPC converter, is an example of such application [27].

Structures similar to the conventional NPC are also widely used. The flying capacitor converter, for example, uses capacitors instead of clamping diodes to divide the dc voltage input. In addition, the balancing of the capacitors can be carried out easily through the modulation. The active NPC (ANPC) converter is another structure, that uses electronic switches to perform the voltage clamping [28, 29]. These two topologies are shown in Fig. 4. Further redundancies in the switching states and better capacitor voltage balancing are advantages of these topologies in relation to the topology with diode clamping. For this reason, some HVDC projects and some $\mathrm{ABB}$ medium voltage drives are based on this topology. Nevertheless, the ANPC topology has a greater number of semiconductor switches, which affects the final cost of the system.

Five-level NPC converters can also be employed in BESS [30]. By increasing the converter levels, it is possible to improve the output voltage waveform and, depending on the number of levels, eliminate the transformer. Thus, BESS can be directly connected to the MV grid.

\section{Transformerless topologies}

Two-level topologies can still be used for direct connection to MV grid, as shown in Fig. 5 [31, 32]. In this configuration, several insulated gate bipolar transistors (IGBTs) are usually connected in series. This connection can be understood as a single IGBT capable to block voltages of some $\mathrm{kV}$. The main disadvantage of this topology is the increased complexity in the gate drive circuits, in order to ensure the synchronization between the on and off states of the switches. It is easy to observe that the greater the numbers of switches in series, the more complex is the converter design. This topology is also designed to operate with low switching frequency, in order to limit the switching losses. However, a low switching frequency increases the filtering requirements.

In relation to the direct connection of BESS to the MV grid, the multilevel topologies have demonstrated prominent technologies in recent researches on BESSs $[10,33]$. These topologies make it easier to deal with the state of charge (SOC) unbalance of the batteries. They also present low losses, modularity and scalability, among other characteristics [34]. The cascaded H-bridge converter $(\mathrm{CHB})$ and the modular multilevel converter with chopper or bridge cells (CC or BC) are two highly discussed multilevel topologies in power storage applications.

The CHB converters, shown in Fig. 6, consist of several cells of single-phase $\mathrm{H}$-bridge converters connected in series in each phase [35-37]. This converter is presented in literature, in star configuration, as shown in Fig. 6 (a), or in the delta configuration, as shown in Fig. 6 (b). The implementation of the star $\mathrm{CHB}$ is less 


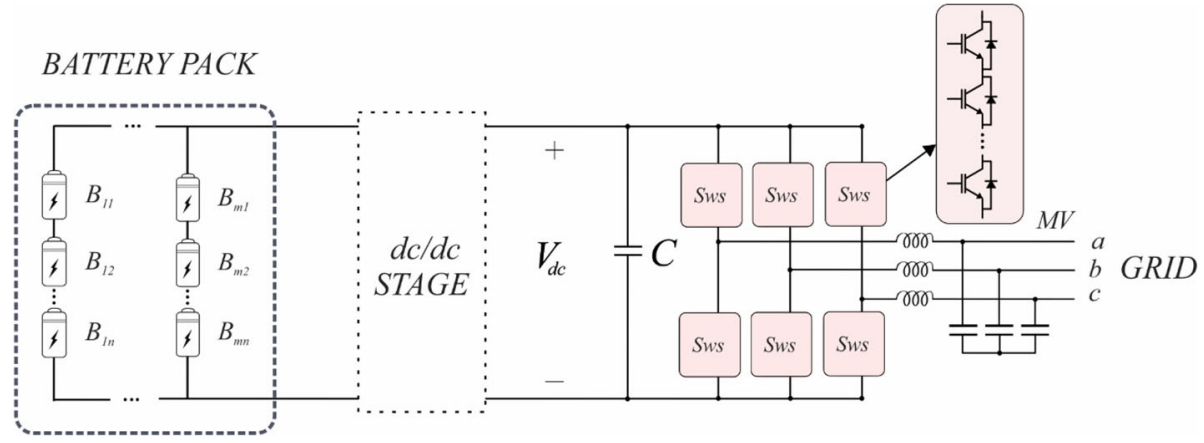

Fig. 5 Transformerless two-level converter connected directly to the grid of MV level

expensive [38], while the delta CHB dynamics is better in situations of grid unbalances [39]. The development of physical systems with $\mathrm{CHB}$ converters has already been achieved. Reference [37] shows the development of a $500 \mathrm{~kW}$ real-scale star CHB for BESS, with successful test results.

The use of the cascade converter topology allows to connect the BESSs directly to the MV grid without step-up transformers [10]. Each H-bridge converter regulates the power flow of each battery (or battery string) connected to its dclink. The inclusion of the dc/dc stage is controversial. Many works use the CHB topologies without the dc-dc stage [34, 35]. On the other hand, other papers argue that it is better to use this stage to improve the lifetime of the batteries [40]. The advantages of the CHB topologies are the inherent advantages of multilevel topologies, such as: the use of low voltage switches, modularity, fault-tolerant, low frequency switching operation and high output voltage quality [19, 41]. The insertion of a zero-sequence voltage between each phase is used to balance the energy between the CHB arms in a star configuration. On the other hand, for the delta CHB arms, the insertion of a zero-sequence current between each phase is used for energy balancing. The high number of switches and, consequently, high costs and high-power losses, raises doubts about the viability of this topology.
The MMC converter, shown in Fig. 7, consists of several single-phase chopper or bridge inverter cells connected in series at each phase [42-44]. This topology has the same advantages inherent to multilevel converters, as already mentioned for the $\mathrm{CHB}$ converter. Besides, it is observed active power support between dc and ac system and a greater freedom of SOC control, since the converter has 3 circulating currents [45-48]. This topology presents flexible disposition of the batteries between the cells of each phase, according to Fig. 7 (a) or between the physical dc-link, according to Fig. 7 (b). The safety of the MMC converter, can be increased by the use a transformer so as to ensure the galvanic isolation of the converter with the grid (MMC + ITx). This principle guarantees the flow of current and consequently, power, without creating forms of metallic conductions, which increases the safety of the system.

Some issues should be investigated when using the MMC topology. For example, if the batteries are connected directly to each cell, unbalances between the voltages can lead to dc current injection into the grid [49]. The dc-dc stage, shown in Fig. 7 (a), decouples the battery from the capacitor, thus reducing the dc filter required and increasing the battery lifetime. Furthermore, the capacitor of the cell can be smaller [50].

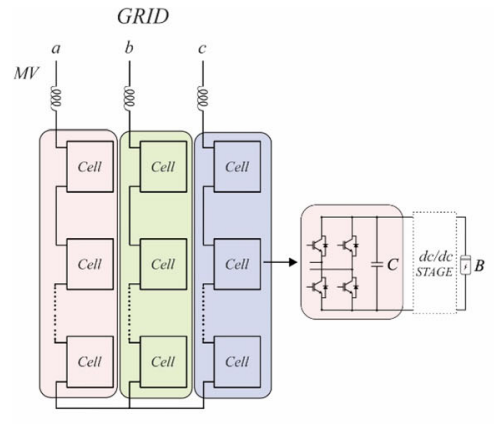

(a)

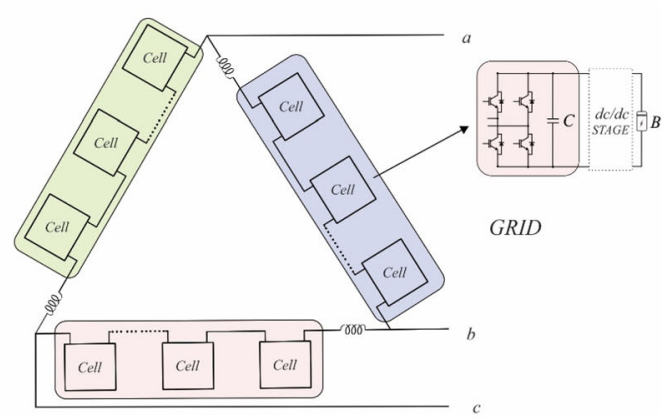

(b)

Fig. $6 \mathrm{CHB}$ converter and the cells composed of single-phase H-bridge converters. a star CHB b delta CHB 


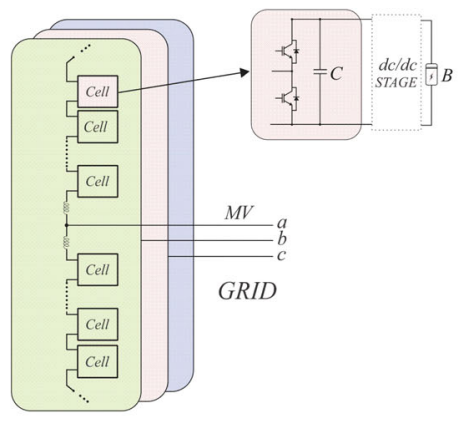

(a)

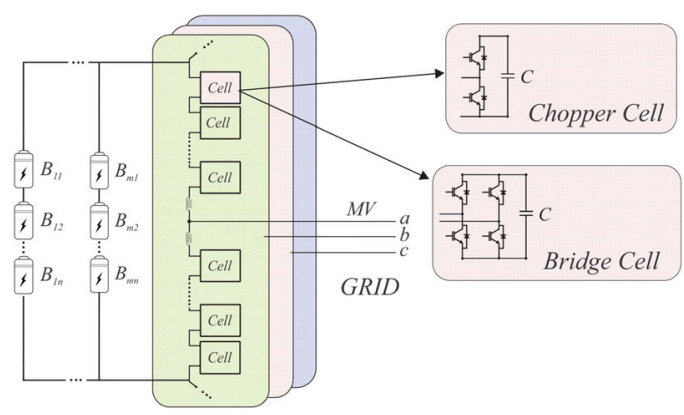

(b)

Fig. $7 \mathrm{MMC}$ - disposition of batteries. a disposition of batteries in cells $\mathbf{b}$ disposition of batteries in dc-link

Another important issue is the impact of the low harmonic order circulating currents between the arms of the dc-ac converter and the batteries [44]. These current components can degrade the battery cells, thus, impacting the battery lifetime [51]. Frequencies below $10 \mathrm{~Hz}$ have the greatest potential to deteriorate the capacity of lithium cells. On the other hand, at levels above $100 \mathrm{~Hz}$, the cells submitted to these components presented a lower level of degradation [52]. Thus, the harmonic second-order current characteristic of the MMC converter can lead to negative impacts on the battery cells. This range of frequencies between 10 and $100 \mathrm{~Hz}$ is still questionable.

\section{BESS control strategies}

Different control strategies can be applied to BESS [7, 33, 53]. However, most of them are based on the same principles of power control cascaded with current control, as shown in Fig. 8. When the dc/dc stage converter is not used, the active power reference for the dc/ac stage control strategy is calculated by the battery SOC during charge process and by grid services requirements under discharge process, as shown in Fig. 8. These services are discussed in the following sections.
In relation to the current control of the dc/ac stage converter, it may be in different reference frames such as natural $a b c$ coordinate, stationary reference frame $(\alpha \beta)$ and synchronous reference frame $(d q)$ [54, 55]. An example of the control strategy based on the stationary reference frame is shown in Fig. 9. However, the active power reference, generated by SOC or for some grid service requirements, and the reactive power reference, the current references $\left(i_{\alpha}^{*}, i_{\beta}^{*}\right)$ for the dc/ac stage converter control are calculated using the instantaneous power theory, given by [56]:

$$
\left[\begin{array}{l}
i_{\alpha}^{*} \\
i_{\beta}^{*}
\end{array}\right]=\frac{1}{v_{\alpha}^{2}+v_{\beta}^{2}}\left[\begin{array}{c}
v_{\alpha} v_{\beta} \\
v_{\beta}-v_{\alpha}
\end{array}\right]\left[\begin{array}{l}
P^{*} \\
Q^{*}
\end{array}\right]
$$

where $v_{g}$ is the grid voltage and $v_{\alpha, \beta}$ are the grid voltage components in the stationary reference frame. The current references are compared with the converter currents $\left(i_{s_{\alpha \beta \beta}}\right)$ and the controllers $G_{c}$ reduce the error between these currents. Finally, a PWM technique calculates the pulses for the converter.

The BESS based on the MMC topology can handle some problems regarding the structure of the converter. The use of chopper cells involves low frequency currents

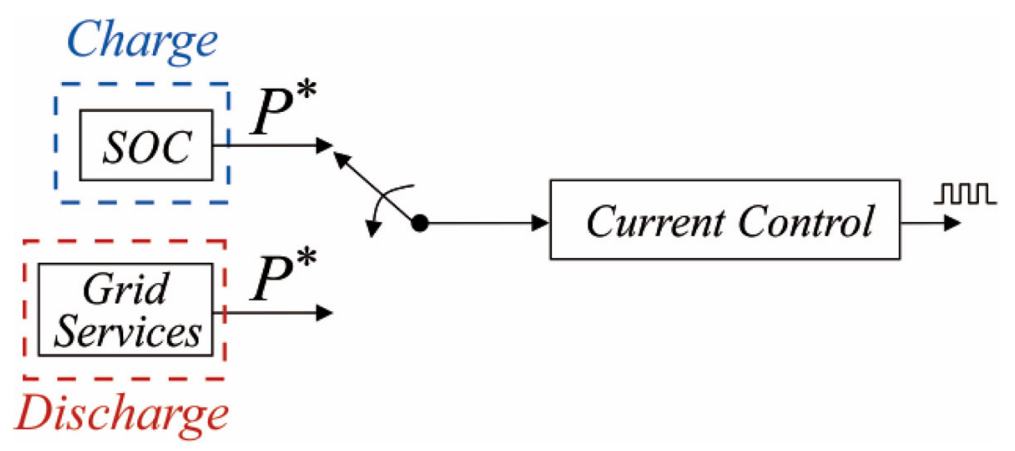

Fig. 8 BESS control strategies 


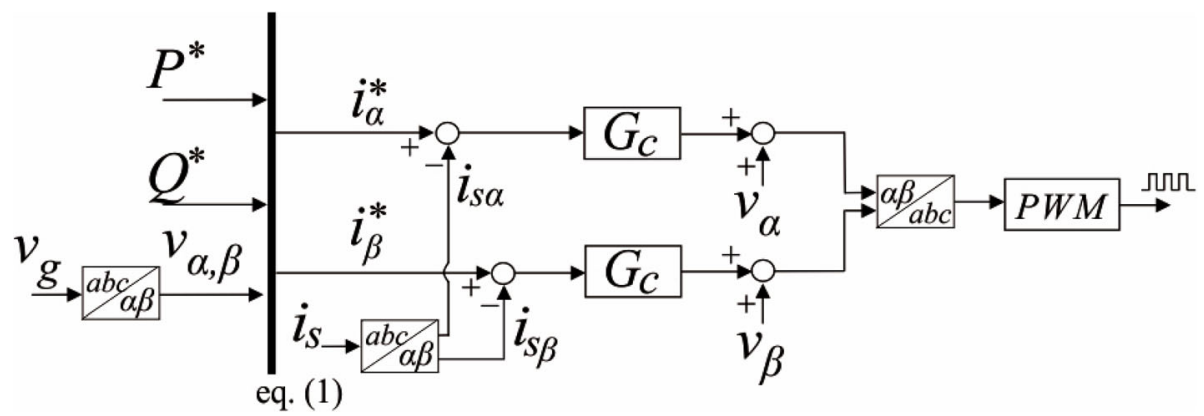

Fig. 9 Current control example of BESS

in the cells and requires interfaces between the battery bank and the cells input, such as the dc-dc stage, which increases the complexity. SOC balancing is another issue, especially in the unbalanced operation, which deals with the unbalanced SOC on converters arms. Thus, it is necessary to control the SOC between the average SOC of each arm and between the difference SOC in the upper and lower arm of each phase.

The MMC control presents two distinct external reference loops to inject or absorb power, similarly to the $2 \mathrm{~L}$ and $3 \mathrm{~L}$ topologies. In case of charging the batteries, a SOC reference is provided to the main current control, as shown in Fig. 10. Besides, the circulating current control is used to control the average and individuals SOC. Finally, these signals are used to the modulation each cell [41].

\section{Services performed by BESS}

The viability of the installation of BESS connected to MV grids depends on the services provided and agreements with the local power system operator. The typical services provided are illustrated in Fig. 11 and described below:
- Peak Shaving: The energy purchased from the utility during peak demand hours can be reduced through BESS. Since the energy price in the peak demand hours is typically more expensive, BESS has become an attractive alternative to companies with high electricity consumption during peak hours. BESS is usually controlled to charge at low demand hours and discharge at the critical time of demand [57-59];

- Transmission and distribution (T\&D) upgrade deferral [60-62]: If there is a constant overload at a specific point in the T\&D lines, the electric utility needs to adapt its infrastructure to support this new demand. However, this is expensive and usually complex, as it may be necessary to upgrade $T \& D$ devices, such as transformer lines, to support the new power flow. An increasingly viable alternative is the installation of BESSs near the overloaded grid point, to reduce the effects on $T \& D$ devices. As a result, the upgrading in the T\&D infrastructure can be delayed or avoided;

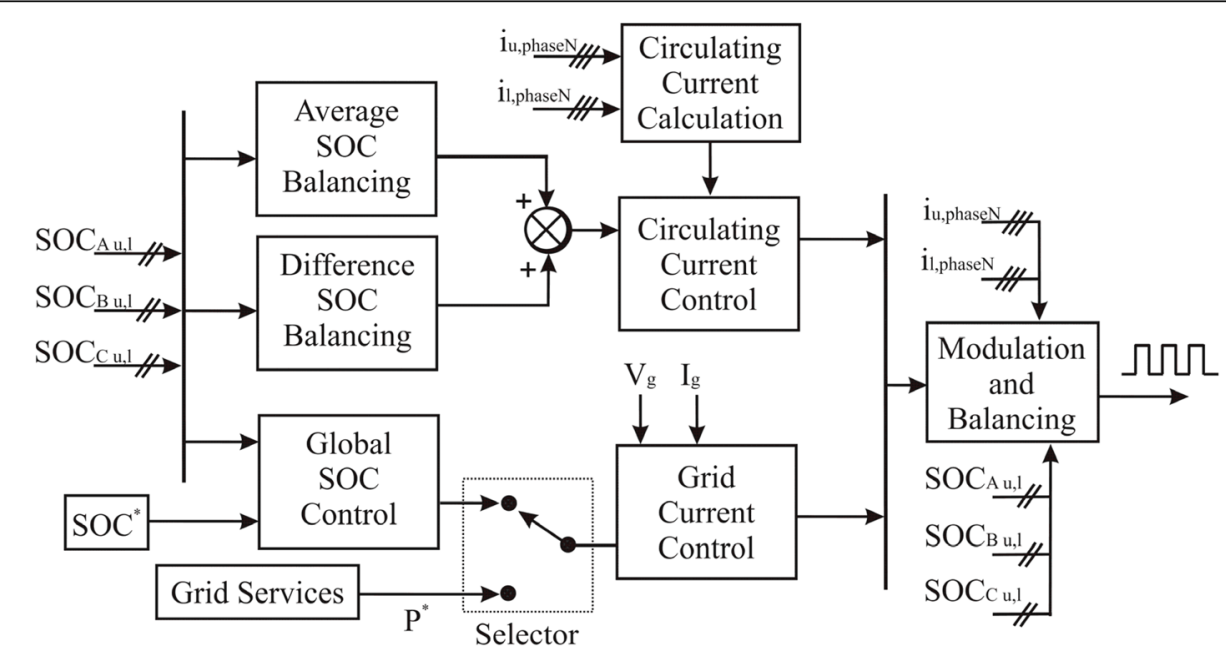

Fig. 10 Overall system control block diagram for MMC-BESS 


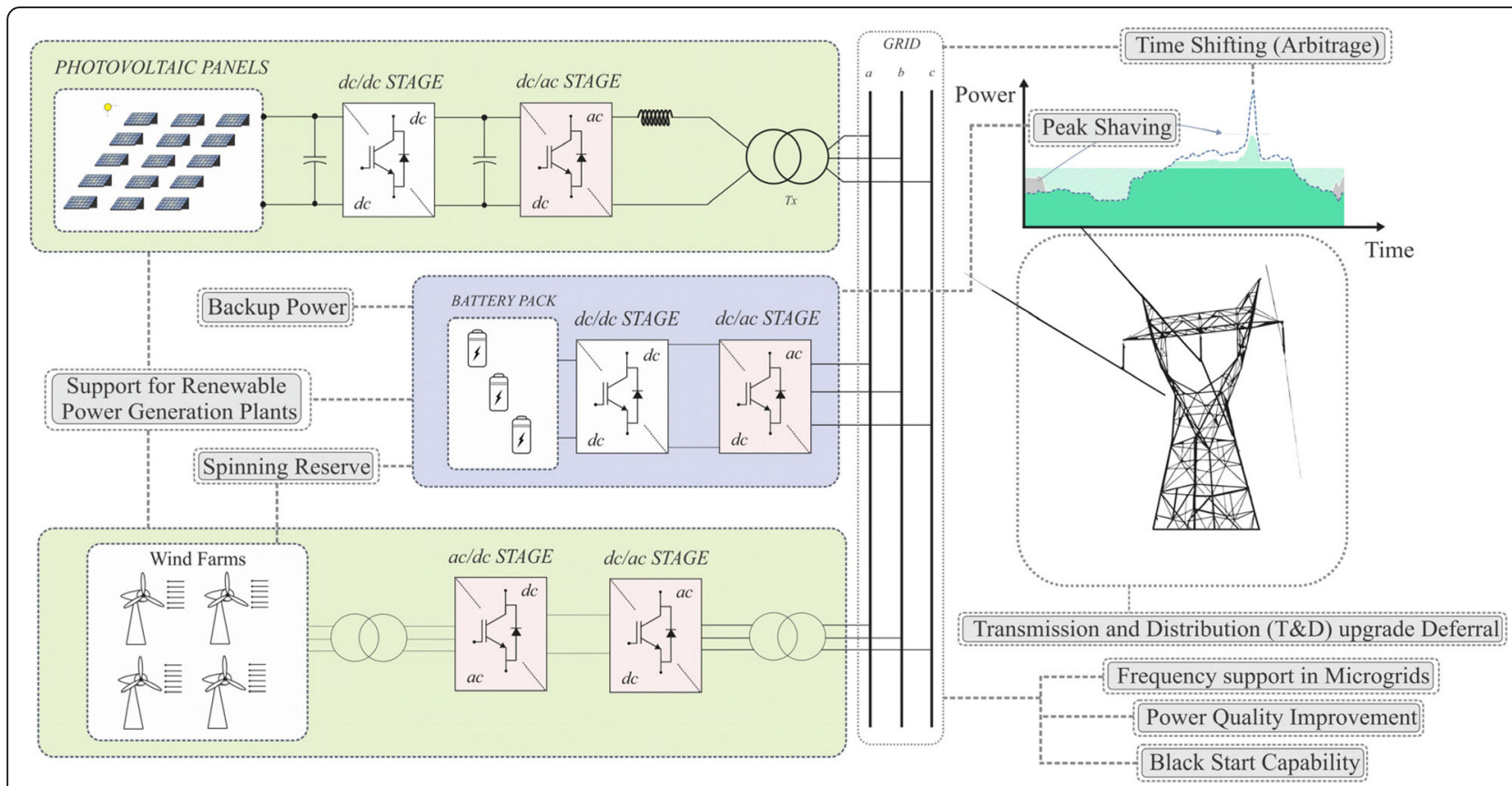

Fig. 11 Services performed by BESS

- Time Shifting (Arbitrage): This is an expression to designate energy trade. Basically, BESS stores energy in hours of low demand, when energy is cheaper, and injects it into the grid in hours of high demand, when energy is more expensive. Therefore, the main benefit is the energy price difference between those hours $[5,63,64]$;

- Support for Renewable Power Generation Plants: The intermittent power generation in renewable energy systems, such as wind or photovoltaic, can be maintained at an appropriate level for a period of time, which alleviates the output power and reduces the rapid oscillations of the voltage and power in the grid $[64,65]$;

- Backup Power: For example, since photovoltaic power plants generate energy only during few hours of the day, especially at low demand times, the BESS system can be used to store this generated energy and supply the loads out of the generation time [53, 66];

- Spinning Reserve: Large power generators usually operate below their total capacity and maintain some reserve to withstand unexpected load variations. It is well known that an overload in the generator tends to reduce its rotation frequency, which affects grid stability. In this scenario, the power reserve is used to increase the torque and recover the nominal rotation of traditional synchronous generators. Studies indicate that BESS can be used to supply this additional power and support the grid during an overload [5, 67]. Therefore, the generator could operate close to its maximum capacity, which means increased energy production;

- Frequency support in microgrids: Recent studies have addressed the ability of microgrids to operate without the grid and BESS ability to provide frequency support and uninterrupted supply in the absence of the main grid $[53,66]$;

- Power Quality improvement: In order to deal with the effects of variation in the grid voltage during periods of high and low demand, different concepts of BESS are proposed to guarantee the voltage quality requirements, especially in scenarios with considerable distributed generation. In this sense, the voltage support and harmonic compensation are applied to the BESS so as to improve aspects of energy quality $[4,68]$; 
- Black Start Capability: Several studies propose the use of BESS to promote the recovery of a total or partial electrical grid subjected to a blackout. Under such conditions, the assistance given by BESS impacts the time of grid interruption and the economic losses [69].

Basically, these functions can be implemented regardless of the converter topology used. The use of a power block structure, as shown in Fig. 3, may have advantages, considering the distribution of these blocks in different points of the grid. Each BESS can provide the services locally and contribute to the whole power system.

\section{Case study}

Since this work is mainly focused on the power converter topologies applied to BESSs, the following topologies were chosen to compare the aspects of a $1 \mathrm{MVA}$ BESS:

- Two-level VSC with transformer (2 L + Tx), shown in Fig. 2;

- Three-level NPC with transformer $(3 \mathrm{~L}+\mathrm{Tx})$, shown in Fig. 4;

- MMC, shown in Fig. 7(a).

- MMC with insulation grid transformer (MMC+ ITx).

The comparisons are based on simulations carried out in the PLECS software system. The main parameters of each converter topology and battery pack information are shown in Table 1.

For the $2 \mathrm{~L}$ and $3 \mathrm{~L}$ converter, four $600 \mathrm{~V} / 500 \mathrm{Ah}$ battery packs are associated in parallel. For the MMC, 600 $\mathrm{V} / 10 \mathrm{Ah}$ battery pack is employed. In all cases, the battery packs are arranged to meet $600 \mathrm{~V}$ for each converter or cell and total power of $1 \mathrm{MW}$.

For sake of simplicity, the dc/dc stage converter was not considered for any topology. All topologies are connected to a $13.8 \mathrm{kV} / 60 \mathrm{~Hz}$ grid. The $2 \mathrm{~L}$ and $3 \mathrm{~L}$ requires a power transformer to step-up the output converter voltage from $380 \mathrm{~V}$ to the grid voltage level. The MMC directly connected to the $13.8 \mathrm{kV}$ grid without transformer. The MMC + ITX presents an insulation transformer (ITx) with turns ratio 1:1.

The converter topologies are compared mainly for efficiency and power losses under different operation conditions. For this purpose, power modules with semiconductor modules with blocking voltage of $1200 \mathrm{~V}$ are selected for all converters. As the $2 \mathrm{~L}$ and $3 \mathrm{~L}$ converters are connected to the low voltage side of the transformer, high current is necessary, which led to the selection of the 1600 A Infineon power module
Table 1 Main parameters of the converter topologies for this case study

\begin{tabular}{|c|c|}
\hline $2 \mathrm{~L}+\mathrm{Tx}$ & Value \\
\hline Battery pack voltage & $600 \mathrm{~V}$ \\
\hline Battery pack charge & $500 \mathrm{Ah}$ \\
\hline Number of battery packs in parallel & 4 \\
\hline Dc-link voltage & $600 \mathrm{~V}$ \\
\hline Switching frequency & $2.4 \mathrm{kHz}$ \\
\hline Converter output voltage & $380 \mathrm{~V}$ \\
\hline Filter equivalent Inductance & $51 \mu H$ \\
\hline Filter $X / R$ ratio & 40 \\
\hline $3 L+T x$ & Value \\
\hline Battery pack voltage & $600 \mathrm{~V}$ \\
\hline Battery pack charge & $500 \mathrm{Ah}$ \\
\hline Dc-link voltage & $600 \mathrm{~V}$ \\
\hline Switching frequency & $1.2 \mathrm{kHz}$ \\
\hline Converter output voltage & $380 \mathrm{~V}$ \\
\hline Inductance filter & $150 \mu H$ \\
\hline Filter $X / R$ ratio & 40 \\
\hline$M M C$ and $M M C+I T x$ & Value \\
\hline Battery cell nominal capacity & $10 \mathrm{Ah}$ \\
\hline Battery cell nominal voltage & $3.6 \mathrm{~V}$ \\
\hline Number of battery cells in series per cell & 167 \\
\hline Dc voltage per cell & $600 \mathrm{~V}$ \\
\hline Dc-link voltage & $21.6 \mathrm{kV}$ \\
\hline Effective switching frequency & $140 \mathrm{~Hz}$ \\
\hline Converter output voltage & $13.8 \mathrm{kV}$ \\
\hline Arm inductance & $16.8 \mathrm{mH}$ \\
\hline Arm inductance $X / R$ ratio & 40 \\
\hline Number of cell per arm & 36 \\
\hline
\end{tabular}

FZ1600R12HP4. The MMC topologies operate directly connected to $13.8 \mathrm{kV}$. In these cases, the $50 \mathrm{~A}$ Infineon FF50R12RT4 is employed.

For the MMC topology, it was considered a dc-link $21.6 \mathrm{kV}$ storage station. Thus, considering a modulation index of 1.05, for the MMC topology with chopper cells, each arm of the converter will contain $N=36$ cells. Considering a $600 \mathrm{~V}$ operating voltage in each cell of the MMC, a $3.6 \mathrm{~V}$ lithium battery cell was designed with a pack of 167 cells. Finally, the arm impedance was taken as $16.83 \mathrm{mH}(0.05 \mathrm{pu})$, and the constant $\mathrm{X} / \mathrm{R}$ of 40 . The power losses associated with the arm inductor were computed from the ohmic losses in the inductor.

\section{Results}

The results are comparatively quantified for power losses at various power levels, total harmonic distortion, device number and energy storage in the inductors and 
capacitors. The quantized power losses are related to the conduction and switching losses of the semiconductors, copper losses of the output filters in the $2 \mathrm{~L}$ and $3 \mathrm{~L}$ converters, copper losses in the arm inductor of the MMC topologies and total losses in the transformer.

In terms of power losses, a set of results are presented with variation ranging from 0.1 to $1 \mathrm{pu}$ of injected active power by the BESS, according to Fig. 12. The results show that the MMC presents the minor losses in relation to the other related topologies and the $3 \mathrm{~L}+\mathrm{Tx}$ converter has the major losses in almost all power range. In the rated power, the topology $3 \mathrm{~L}+\mathrm{Tx}$ has power losses almost four times higher than the MMC and three times higher than $2 \mathrm{~L}+\mathrm{Tx}$. The analysis of the losses associated to the isolation transformer in the MMC converter (MMC + ITx) shows that it is two times higher than the MMC directly connected to the grid, which demonstrates the impact of the use of a connection transformer.

The MMC topology presented the minor power losses, since each cell processes less power than the converters of the $2 \mathrm{~L}$ and $3 \mathrm{~L}$ topologies. Furthermore, these last topologies present high inductive elements in the converter output, due to higher filtering requirements and the presence of the connection transformer.

Once the values of the power losses are obtained, the efficiency values of the topologies for different injected power levels are quantified and shown in Fig. 13. All topologies presented efficiency superior to 94\%. The MMC topology presented higher efficiency levels for all cases of injected power, followed by the MMC + ITx topology. The $2 \mathrm{~L}+\mathrm{Tx}$ converter showed an efficiency higher than 96\%, which is higher than the $3 \mathrm{~L}+\mathrm{Tx}$ converter above $0.4 \mathrm{pu}$ of injected power. The $2 \mathrm{~L}+\mathrm{Tx}$ converter presented the least efficiency at low power levels.

The power losses are detailed for each topology at nominal power $(1 \mathrm{pu})$, as shown in Fig. 14. In Fig. 14(a), the power losses of the converter $2 \mathrm{~L}+\mathrm{Tx}$ is concentrated in the step-up transformer (35\%), and the semiconductor conduction and switching have similar impacts on the power losses 26 and $24 \%$, respectively. The copper losses in the filter inductor account responsible for $14 \%$ of the total losses.

On the other hand, the $3 \mathrm{~L}+\mathrm{Tx}$ topology presented the highest losses in the semiconductor conduction (38\%), as shown in Fig. 14(b), while the transformer and the inductor filter account for 26 and $31 \%$, respectively. Notice that, since the switching frequency of the $3 \mathrm{~L}$ converter is less than $2 \mathrm{~L}$, the switching losses contribute with only $5 \%$ for the total losses.

Figure 14(c) shows the power losses for the MMC topology, the conduction losses characterize more than $75 \%$ of the total losses and concentrate the largest percentage term in relation to the other converters. Considering the use of a transformer in the MMC topology, as observed in Fig. 14(d) the losses of the transformers exceed those of conduction and are the most significant in this case. For both cases of MMC topologies, the switching losses are less than $1 \%$, which is the least contribution.

Table 2 presents other relevant parameters for the assessment of topologies. In relation to the total harmonic distortion (THD) of the injected current by the

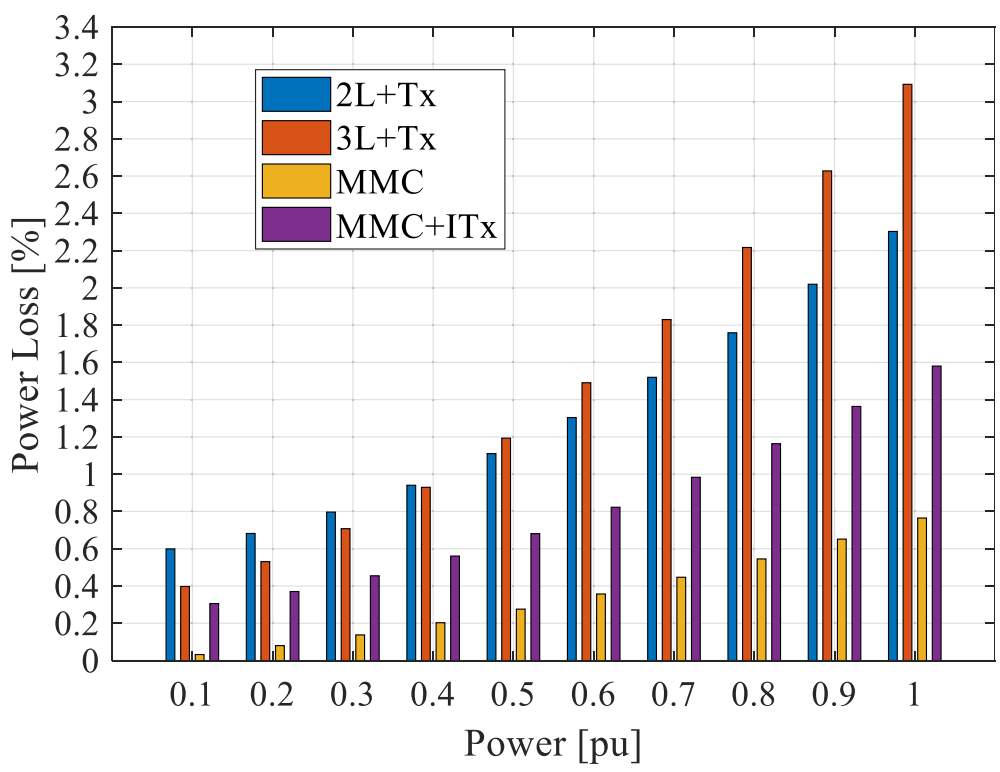

Fig. 12 Comparison of the power losses for each converter topology at various power levels 


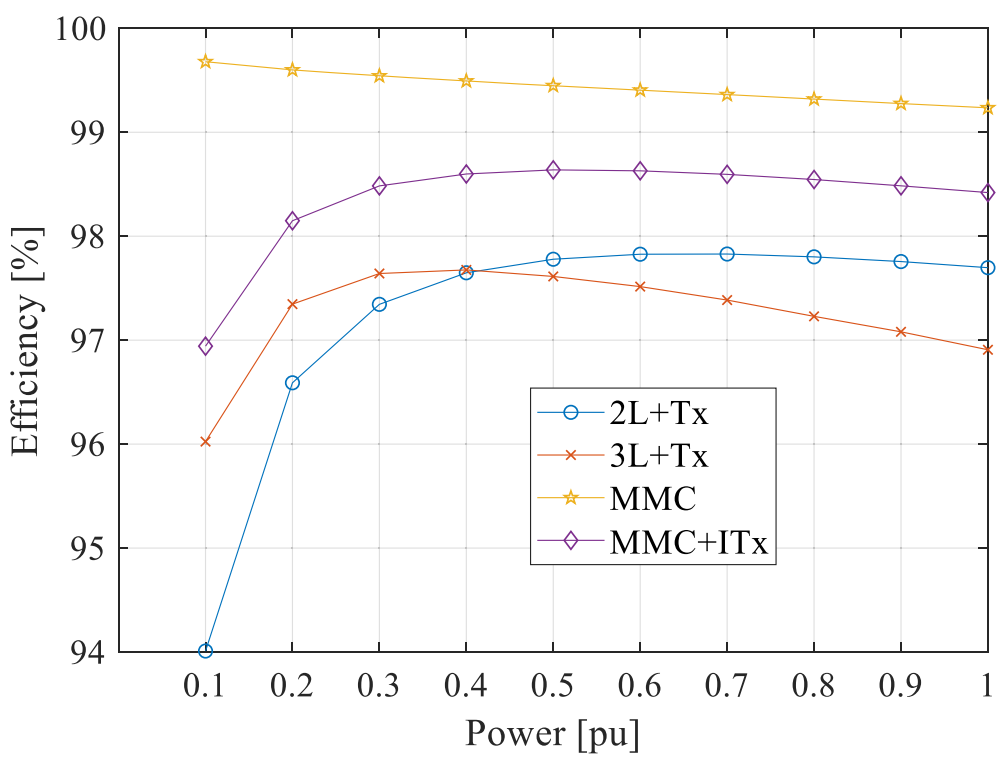

Fig. 13 Efficiency for each converter topology at various power levels

BESS into the grid, the MMC inverter presented the lowest value among the other topologies, with a distortion of less than $1 \%$, mainly due to its ability to synthesize a voltage with a higher number of output levels. The $2 \mathrm{~L}$ and $3 \mathrm{~L}$ present the THD of the injected current equal to 2.52 and $3.48 \%$, respectively. The current waveforms for each topology are shown in Fig. 15. The higher current distortion of the $3 \mathrm{~L}$ topology is due to the low switching frequency generally adopted for this converter.

The impact of the passive components, such as inductor and capacitor, on the cost of the converter is related with the energy storage requirements in these elements. For the $2 \mathrm{~L}+\mathrm{Tx}$ and $3 \mathrm{~L}+\mathrm{Tx}$ topologies, the total stored energy values in the filter inductors and dclink capacitor are given, respectively, by:

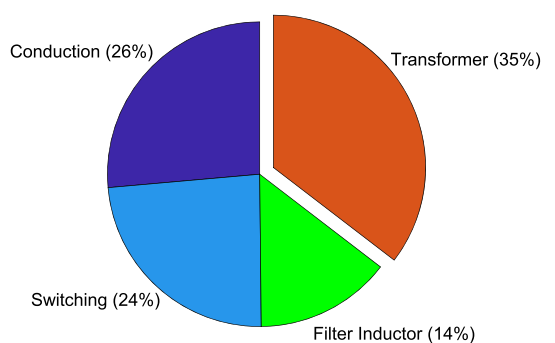

(a)

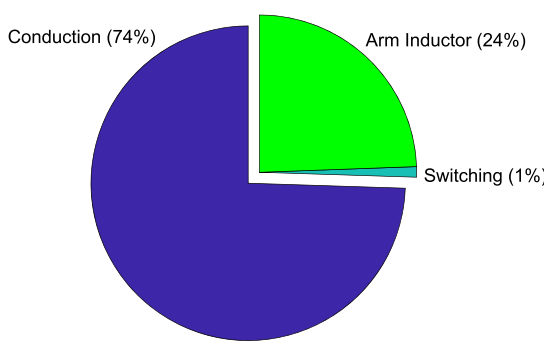

(c)

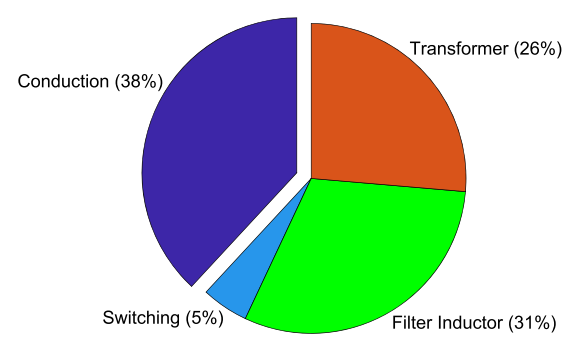

(b)

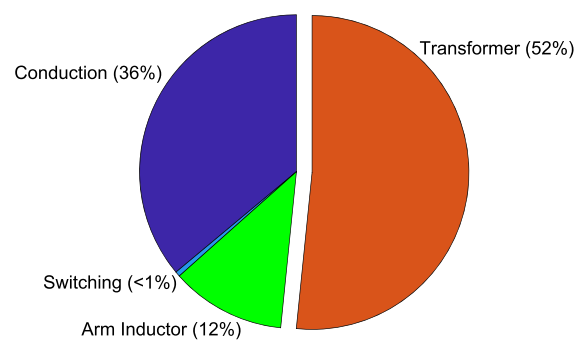

(d)

Fig. 14 Detailing of losses between conduction, switching, inductor and transformer at nominal power (1 pu). a $2 L+T x$. b $3 L+T x$. c MMC. d $M M C+I T x$ 
Table 2 Comparison about $2 L+T x, 3 L+T x, M M C$ and $M M C+$ ITX

\begin{tabular}{lllll}
\hline Comparison & $2 \mathrm{~L}+\mathrm{Tx}$ & $3 \mathrm{~L}+\mathrm{Tx}$ & $\mathrm{MMC}$ & $\mathrm{MMC}+\mathrm{ITx}$ \\
\hline Efficiency at rated power (\%) & 97.70 & 96.91 & 99.23 & 98.42 \\
THD at rated power (\%) & 2.52 & 3.48 & 0.87 & 0.87 \\
THD at rated power (\%) & 4000 & 4000 & 40,000 & 40,000 \\
Inductor Energy Storage (J) & 360 & 1050 & 45.5 & 45.5 \\
Number of IGBTs & 6 & 12 & 432 & 432 \\
Number of Diodes & 6 & 18 & 432 & 432 \\
Number of Control Loops & 3 & 3 & 12 & 12 \\
Number of Current Sensors & 3 & 3 & 6 & 6 \\
Number of Voltage Sensors & 4 & 4 & 4 & 4 \\
Fault Tolerance & No & No & Yes & Yes
\end{tabular}

$$
\begin{aligned}
& E_{\text {ind }}=\frac{3}{2} L I_{n}^{2} \\
& E_{\text {cap }}=\frac{1}{2} C V_{d c}^{2}
\end{aligned}
$$

where $\mathrm{L}$ is the inductance per phase, $I_{n}$ is the nominal current, $C$ is the dc-link capacitance and $V_{d c}$ is the dclink voltage. Energy storage is an indirect measurement of the volume of the components [40].

According to [70], $2 \mathrm{~L}$ and $3 \mathrm{~L}$ converters have an energy storage requirement in the dc-link between 2 and $4 \mathrm{~J} / \mathrm{kVA}$.
Therefore, both $2 \mathrm{~L}$ and $3 \mathrm{~L}$ presented equal stored energy requirements in the dc-link capacitor around $4000 \mathrm{~J}$. For the inductor, the stored energy is $360 \mathrm{~J}$ and $1050 \mathrm{~J}$ for $2 \mathrm{~L}$ and $3 \mathrm{~L}$, respectively. Thus, the MMC topology presents a higher stored energy requirement for the capacitors, which increases the cost by ten times, while for the energy stored in the inductors, it presents a lower cost for the MMC converter, compared to the $2 \mathrm{~L}$ topologies and $3 \mathrm{~L}$, namely, eight and twenty-four times, respectively.

The energy storage in the passive components for the MMC topology can be obtained from equations below:

$$
\begin{aligned}
& E_{\text {ind }}=\frac{6}{2} L I_{n}^{2} \\
& E_{\text {cap }}=\frac{6 N}{2} C \mathrm{~V}_{\mathrm{dc}}^{2}
\end{aligned}
$$

where $I_{n}, N$, and $V_{d c}$ designate the nominal arm current, number of cells per arm, and average operating voltage of the capacitor, respectively. The stored energy requirements for the MMC topologies is $40 \mathrm{~J} / \mathrm{kVA}$, according to [34]. Therefore, the energy storage is $40,000 \mathrm{~J}$ and $45.5 \mathrm{~J}$ for capacitor and inductor, respectively.

The number of semiconductors is smaller for the $2 \mathrm{~L}$ converter. The MMC presented higher number of semiconductors due to the various cells. The number of current sensors for $2 \mathrm{~L}$ and $3 \mathrm{~L}$ is 3 , i.e., one sensor for each phase.

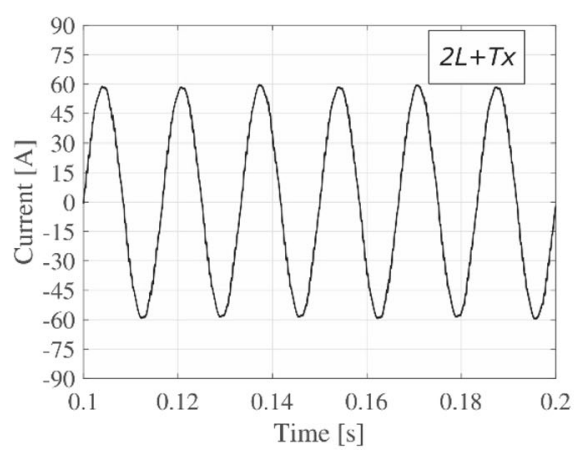

(a)

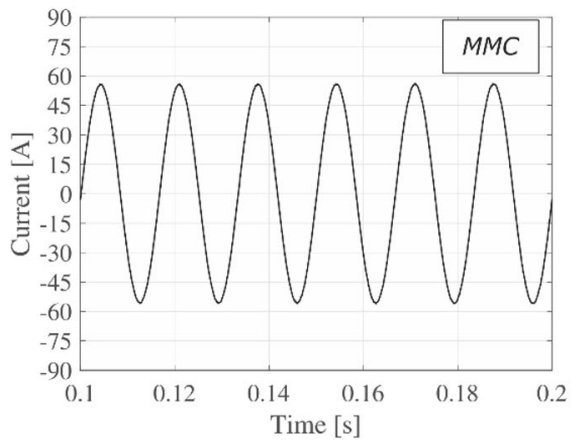

(c)

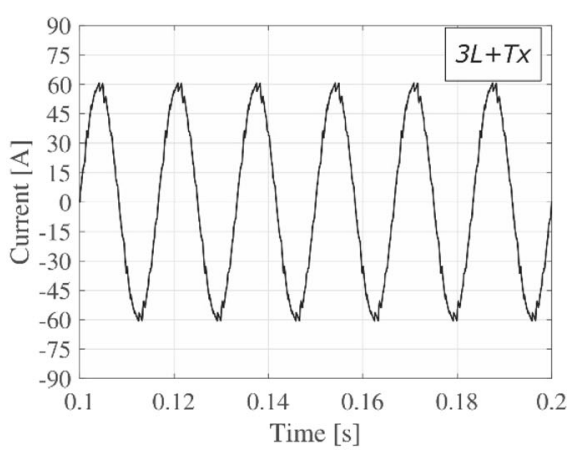

(b)

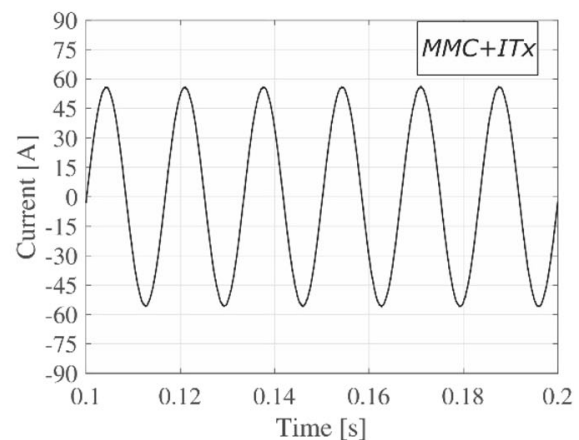

(d)

Fig. 15 Current waveforms injected by BESS into the grid. a $2 L+T x$. b $3 L+T x . \mathbf{c} M M C$. d MMC + ITX 
Furthermore, 4 voltage sensors are required, one to measure the dc-link voltage and 3 to measure the ac line voltage. The current sensors are used in the MMC to measure the arm currents of each phase, revealing a measurement number two times greater than the measurements when topologies $2 \mathrm{~L}$ and $3 \mathrm{~L}$ are compared. Furthermore, 3 voltage sensors are required to measure the ac line voltage, besides one to the voltage from the dc-link pole to pole. The number of sensors has a slight impact on the system costs, but can affect its reliability.

The fault tolerance is a characteristic of the MMC, i.e., if one or more cells present failures, they can be removed from the system and the system can continue in operation. This characteristic ensures a higher faulttolerance of the MMC compared to the $2 \mathrm{~L}$ and $3 \mathrm{~L}$ converters.

\section{Conclusion}

This work presented a literature review on the converter topologies commonly employed in BESS connected to MV grids. Furthermore, a case study is performed to compare some converter topologies to connect the BESS to the grid. It can be concluded that, although the two-level and threelevel topologies present a step-up transformer for the connection with the medium voltage grid, which means higher losses, they are still preferable due to their physical and control simplicity if compared with the MMC topologies. However, due to the low losses and greater reliability, it is possible to verify a growing trend of using MMC topologies in BESS applications.

Energy storage systems raise controversial opinions in the literature, and have been among the most discussed issues in recent works. Challenges such as handling the battery lifetime for low frequency cycles and feasibility of the inclusion of the $\mathrm{dc} / \mathrm{dc}$ stage are presented as uncertain topics. Besides, aspects related to optimization of BESS, impact the analysis of operating costs, power losses, energy quality and lifetime evaluation.

Another important issue to determine the feasibility of the project is the BESS services, which can be used to obtain an efficient system, maximizing the investment payback. Recent studies show that BESS can contribute even more to the expansion of renewable sources in the electric system and reduce the impacts related to the intermittent generation of these sources.

\footnotetext{
Abbreviations

2 L: Two-level; 3 L: Three-level; ac: Alternating current; ANPC: Active neutralpoint clamped; BC: Bridge cell; BESS: Battery energy storage systems; CC: Chopper cell; CHB: Cascaded H-bridge converter; dc: Direct current; HVDC: High voltage direct current; IGBTs: Insulated gate bipolar transistors; IT : Insulation transformer; LC: Inductor-capacitor; LCL: Inductor-capacitorinductor; LV: Low voltage; MMC: Modular multilevel converter; MV: Medium voltage; NPC: Neutral-point clamped; qZSI: Quasi-Z-source converter; SEPIC: Single-ended primary-inductor converter; SOC: State of charge; T\&D: Transmission and distribution; $T_{\times}$: Transformer; VSC: Voltage source converter; ZSI: Z-source converter
}

\section{Acknowledgements}

The authors are thankful to CNPq (Conselho Nacional de Desenvolvimento Científico e Tecnológico), FAPEMIG (Fundação de Amparo à Pesquisa do estado de Minas Gerais) CAPES (Coordenação de Aperfeiçoamento de Pessoal de Nível Superior), and CEMIG (Companhia Energética de Minas Gerais) for their assistance and financial support.

\section{Authors' contributions}

LSX is the main author of this work. This paper provides a further elaboration of some of the results associated to his Ph.D, where he carried out studies regarding comparisons of topologies with transformers and transformerless applied in battery energy storage systems, as well as a review of services. WCSA made a comparison among topologies performed with converters and without transformers, especially MMC converters, which is part of his master's work. AFC, HAP and VFM have supervised this work. WCB held a general supervision over the performed work. All authors have been involved in the preparation of the manuscript. Besides, all authors read and approved the final manuscript.

\section{Funding}

This work is supported by the R\&D project CEMIG/ANEEL number D722. CEMIG company is paying a $\mathrm{PhD}$ and a master scholarships.

\section{Availability of data and materials}

All data generated or analysed during this study are included in this published article.

\section{Competing interests}

The authors declare that they have no competing interests.

\section{Author details}

${ }^{1}$ Graduate Program in Electrical Engineering, Federal University of Minas Gerais, Av. Pres. Antônio Carlos, Belo Horizonte, MG 6627, Brazil. ${ }^{2}$ Federal Center for Technological Education of Minas Gerais, Av. Amazonas 5253, Belo Horizonte, MG 30421-169, Brazil. ${ }^{3}$ Department of Electrical Engineering, Federal University of Viçosa, Av. P. H. Rolfs s/n, 36570-900, Vicosa, MG, Brazil.

Received: 5 December 2018 Accepted: 31 May 2019

Published online: 16 July 2019

\section{References}

1. Baker JN, Collinson A. Electrical energy storage at the turn of the millennium. Power Eng J. 1999;13(3):107-12

2. Chen H, Cong TN, Yang W, Tan C, Li Y, Ding Y. Progress in electrical energy storage system: a critical review. Prog Nat Sci. 2009;19(3):291-312.

3. Horiba T. Lithium-ion battery systems. Proc IEEE. 2014;102(6):939-50.

4. Feehally $T$, et al. Battery energy storage systems for the electricity grid: UK research facilities. In: 8th IET International Conference on Power Electronics, Machines and Drives (PEMD 2016); 2016.

5. Xu X, Bishop M, Oikarinen DG, Hao C. Application and modeling of battery energy storage in power systems. J Power Energy Syst. 2016;2(3):82-90.

6. Gallardo-Lozano J, Milanés-Montero MI, Guerrero-Martínez MA, RomeroCadaval E. Electric vehicle battery charger for smart grids. Electr Power Syst Res. 2012;90:18-29.

7. Qian H, Zhang J, Lai JS, Yu W. A high-efficiency grid-tie battery energy storage system. IEEE Trans Power Electron. 2011;26(3):886-96.

8. Zhou H, Bhattacharya T, Tran D, Siew TST, Khambadkone AM. Composite energy storage system involving battery and ultracapacitor with dynamic energy management in microgrid applications. IEEE Trans Power Electron. 2011;26(3):923-30

9. Chatzinikolaou E, Rogers DJ. A comparison of grid - connected battery energy storage system designs. IEEE Trans Power Electron. 2017;32(9): 6913-23.

10. Maharjan L, Inoue S, Akagi H. A transformerless energy storage system based on a cascade multilevel PWM converter with star configuration. IEEE Trans Ind Appl. 2008:44(5):1621-30.

11. Wang $G$, et al. A review of power electronics for grid connection of utilityscale battery energy storage systems. IEEE Trans Sustain Energy. 2016;7(4): 1778-90. 
12. Vazquez S, Lukic SM, Galvan E, Franquelo LG, Carrasco JM. Energy storage systems for transport and grid applications. IEEE Trans Ind Electron. 2010; 57(12):3881-95.

13. Krishnamoorthy HS, Rana D, Garg P, Enjeti PN, Pitel IJ. Wind turbine generator-battery energy storage utility interface converter topology with medium-frequency transformer link. IEEE Trans Power Electron. 2014;29(8): 4146-55.

14. Peng FZ. Z-source inverter. IEEE Trans Ind Appl. 2003;39(2):504-10.

15. Anderson J, Peng FZ. Four quasi-Z-Source inverters. In: IEEE power electronics specialists conference; 2008.

16. Cintron-Rivera JG, Li Y, Jiang S, Peng FZ. Quasi-Z-source inverter with energy storage for photovoltaic power generation systems. In: IEEE applied power electronics conference and exposition; 2011

17. Liu Y, Ge B, Abu-Rub H, Peng FZ. Control system design of battery-assisted quasi-z-source inverter for grid-tie photovoltaic power generation. IEEE Trans Sustain Energy. 2013;4(4):994-1001.

18. Lawder MT, et al. Battery energy storage system (BESS) and battery management system (BMS) for grid-scale applications. Proc IEEE. 2014; 102(6):1014-30.

19. Ota JIY, Sato T, Akagi H. Enhancement of performance, availability, and flexibility of a battery energy storage system based on a modular multilevel cascaded converter (MMCC-SSBC). IEEE Trans Power Electron. 2016;31(4): 2791-9.

20. D. Cicio, G. Product, M. Energy, and S. Solutions, "EssPro ${ }^{\mathrm{T} M}$ - battery energy storage the power to control energy challenges of the future power grid long-term drivers for energy storage," 2017. Available: https://new.abb.com/ docs/librariesprovider78/eventos/jjtts-2017/presentaciones-peru/(dario-cicio)bess\%2D\%2D-battery-energy-storage-system.pdf?sfvrsn=2. [Accessed: 24 Sep 2018].

21. DOE. DOE global energy storage database. In: Office of electricity delivery \& energy reliability. [Online]. Available: http://www.energystorageexchange. org/. [Accessed: 24-Sep-2018].

22. IPL. The challenges of integrating lithium ion battery storage arrays in MISO. In: PJM Primary frequency response senior task force; 2017. [Online]. Available: https://www.pjm.com/-/media/committees-groups/task-forces/pfrstf/ 20171009/20171009-item-03-aes-ipl-advancion-energy-storage-array-pfr.ashx [Accessed: 24 Sep 2018]

23. Tabart Q, Vechiu I, Etxeberria A, Bacha S. Hybrid Energy storage system microgrids integration for power quality improvement using four-leg threelevel NPC inverter and second-order sliding mode control. IEEE Trans Ind Electron. 2018;65(1):424-35.

24. Jayasinghe SDG, Vilathgamuwa DM, Madawala UK. A battery energy storage interface for wind power systems with the use of grid side inverter. In: IEEE Energy conversion congress and exposition; 2010.

25. Arifujjaman M. A comprehensive power loss, efficiency, reliability and cost calculation of a $1 \mathrm{MW} / 500 \mathrm{kWh}$ battery based energy storage system for frequency regulation application. Renew Energy. 2015:74:158-69.

26. Pou J, Pindado R, Boroyevich D, Rodríguez P. Evaluation of the lowfrequency neutral-point voltage oscillations in the three-level inverter. IEEE Trans Ind Electron. 2005;52(6):1582-8.

27. ABB, "DynaPeaQ Energy Storage System - A UK first." [Online]. Available: https://new.abb.com/facts/references/reference-dynapeaq\%2D\%2D-a-ukfirst. [Accessed: 28 Sep 2018].

28. Meynard TA, Foch H. Multi-level conversion: high voltage choppers and voltage-source inverters. In: 23rd annual IEEE power electronics specialists conference; 1992.

29. Li J, Huang AQ, Bhattacharya S, Tan G. Three-level active neutral-pointclamped (ANPC) converter with fault tolerant ability. In: IEEE applied power electronics conference and exposition - APEC; 2009.

30. Srikanth KS. A three phase multi level converter for grid connected PV system. Int J Power Electron Drive Syst. 2014;5(1):71-5.

31. Abe Y, Maruyama K, Matsumoto Y, Sasagawa K, Matsuse K. Performance of IGBTS series connection technologies for auxiliary power supply system. In: Power conversion conference - Nagoya; 2007.

32. Sasagawa K, Abe Y, Matsuse K. Voltage-balancing method for IGBTs connected in series. IEEE Trans Ind Appl. 2004;40(4):1025-30.

33. Maharjan L, Yamagishi T, Akagi $H$. Active-power control of individual converter cells for a battery energy storage system based on a multilevel cascade PWM converter. IEEE Trans Power Electron. 2012;27(3):1099-107.

34. Cupertino AAF, Farias JVM, Pereira HA, SelemeJr SI, Teodorescu R. DSCC MMC STATCOM Main circuit parameters design considering positive and negative sequence compensation. J Control Autom Electr Syst. 2018;29(1): 62-74.

35. Hagiwara M, Akagi H. Control and experiment of Pulsewidth-modulated modular multilevel converters. IEEE Trans Power Electron. 2009;24(7):1737-46.

36. Thomas S, Stieneker M, De Doncker RW. Development of a modular highpower converter system for battery energy storage systems. In: 14th European conference on power electronics and applications; 2013.

37. Kawakami $\mathrm{N}$, et al. Development of a 500-kW modular multilevel cascade converter for battery energy storage systems. IEEE Trans Ind Appl. 2014; 50(6):3902-10.

38. Akagi $\mathrm{H}$. Classification, terminology, and application of the modular multilevel cascade converter (MMCC). IEEE Trans Power Electron. 2011; 26(11):3119-30.

39. Sochor $\mathrm{P}$, Akagi $\mathrm{H}$. Theoretical comparison in energy-balancing capability between star- and delta-configured modular multilevel cascade inverters for utility-scale photovoltaic systems. IEEE Trans Power Electron. 2016;31(3): 1980-92.

40. Hillers A, Stojadinovic M, Biela J. Systematic comparison of modular multilevel converter topologies for battery energy storage systems based on split batteries. In: 17th European conference on power electronics and applications; 2015.

41. Vasiladiotis M, Rufer A. Analysis and control of modular multilevel converters with integrated battery energy storage. IEEE Trans Power Electron. 2015;30(1):163-75.

42. Vasiladiotis $\mathrm{M}$, Cherix $\mathrm{N}$, Rufer $\mathrm{A}$. Impact of grid asymmetries on the operation and capacitive energy storage design of modular multileve converters. IEEE Trans Ind Electron. 2015;62(11):6697-707.

43. Lachichi A. Modular multilevel converters with integrated batteries energy storage. In: International conference on renewable energy research and application; 2014.

44. Trintis I, Munk-Nielsen S, Teodorescu R. A new modular multilevel converter with integrated energy storage. In: 37th Annual Conference of the IEEE Industrial Electronics Society; 2011.

45. Soong T, Lehn PW. Internal power flow of a modular multilevel converter with distributed energy resources. IEEE J Emerg Sel Top Power Electron. 2014:2(4):1127-38

46. Soong T, Lehn PW. Assessment of fault tolerance in modular multilevel converters with integrated energy storage. IEEE Trans Power Electron. 2016; 31(6):4085-95.

47. Chen Q, Li R, Cai X. Analysis and fault control of hybrid modular multilevel converter with integrated battery energy storage system. IEEE J Emerg Sel Top Power Electron. 2017;5(1):64-78.

48. Li N, Gao F, Hao T, Ma Z, Zhang C. SOH balancing control method for the MMC battery energy storage system. IEEE Trans Ind Electron. 2018;65(8): 6581-91.

49. Gao F, Zhang L, Zhou Q, Chen M, Xu T, Hu S. State-of-charge balancing control strategy of battery energy storage system based on modular multilevel converter. In: IEEE Energy conversion congress and exposition; 2014

50. Soong T, Lehn PW. Evaluation of emerging modular multilevel converters for BESS applications. IEEE Trans Power Deliv. 2014;29(5):2086-94.

51. Uddin K, Moore AD, Barai A, Marco J. The effects of high frequency current ripple on electric vehicle battery performance. Appl Energy. 2016;178:142-54.

52. Uno M, Tanaka K. Influence of high-frequency charge-discharge cycling induced by cell voltage equalizers on the life performance of lithium-ion cells. IEEE Trans Veh Technol. 2011:60(4):1505-15.

53. Serban I, Marinescu C. Control strategy of three-phase battery energy storage systems for frequency support in microgrids and with uninterrupted supply of local loads. IEEE Trans Power Electron. 2014;29(9): 5010-20.

54. Xavier LS, Cupertino AF, Pereira HA. Ancillary services provided by photovoltaic inverters : single and three phase control strategies R. Comput Electr Eng. 2018;70:102-21

55. Blaabjerg F, Teodorescu R, Liserre M, Timbus AV. Overview of control and grid synchronization for distributed power generation systems. IEEE Trans Ind Electron. 2006:53(5):1398-409.

56. Akagi $H$, Kanazawa $Y$, Nabae $A$. Instantaneous reactive power compensators comprising switching devices without energy storage components. IEEE Trans Ind Appl. 1984;|A-20(3):625-30.

57. De Salis RT, Clarke A, Wang Z, Moyne J, Tilbury DM. Energy storage control for peak shaving in a single building. In: IEEE PES general meeting | conference \& exposition; 2014 
58. Wang $\mathrm{B}$, Zarghami $\mathrm{M}$, Vaziri $\mathrm{M}$. Energy management and peak-shaving in grid-connected photovoltaic systems integrated with battery storage. North Am Power .... 2016.

59. Prasatsap U, Kiravittaya S, Polprasert J. Determination of optimal energy storage system for peak shaving to reduce electricity cost in a university. Energy Procedia. 2017;138:967-72

60. Eyer $J$. Electric utility transmission and distribution upgrade deferral benefits from modular electricity storage. Albuquerque and Livermore: A study for the DOE energy storage systems program, Sandia National Laboratories; 2009.

61. Garcia-Garcia L, Paaso EA, Avendano-Mora M. Assessment of battery energy storage for distribution capacity upgrade deferral. In: IEEE Power \& energy society innovative smart grid technologies conference; 2017.

62. Zhang T, Member S, Emanuel AE, Fellow L, Orr JA, Fellow L. Distribution feeder upgrade deferral through use of energy storage systems. In: IEEE power and energy society general meeting; 2016.

63. Walawalkar R, Apt J, Mancini R. Economics of electric energy storage for energy arbitrage and regulation in New York. Energy Policy. 2007;35(4): 2558-68.

64. Abdelrazek SA, Kamalasadan S. Integrated PV capacity firming and Energy time shift battery Energy storage management using energy-oriented optimization. Trans Ind Appl. 2016;52(3):2607-17.

65. Li X, Hui D, Lai X. Battery energy storage station (BESS)-based smoothing control of photovoltaic (PV) and wind power generation fluctuations. IEEE Trans Sustain Energy. 2013;4(2):464-73.

66. Velasco $D$, et al. Photovoltaic power system with battery backup with gridconnection and islanded operation capabilities. Trans Ind Electron. 2013; 60(4):1571-81.

67. Knap V, Chaudhary SK, Stroe DI, Swierczynski M, Craciun BI, Teodorescu R. Sizing of an energy storage system for grid inertial response and primary frequency reserve. IEEE Trans Power Syst. 2016;31(5):3447-56.

68. Krata J, Saha TK. Real-time coordinated voltage support with battery energy storage in a distribution grid equipped with medium-scale PV generation. IEEE Trans Smart Grid, no. In Press. 2018;10(3):3486-97.

69. Xu Z, Yang P, Zheng Q, Zeng Z. Study on black start strategy of microgrid with PV and multiple energy storage systems. In: 18th international conference on electrical machines and systems; 2015.

70. Sharifabadi K, Harnefors L, Nee H-P. Teodorescu R, Norrga S. Design, control, and application of modular multilevel converters for HVDC transmission systems. New York: Wiley; 2016

\section{Publisher's Note}

Springer Nature remains neutral with regard to jurisdictional claims in published maps and institutional affiliations.

Ready to submit your research? Choose BMC and benefit from:

- fast, convenient online submission

- thorough peer review by experienced researchers in your field

- rapid publication on acceptance

- support for research data, including large and complex data types

- gold Open Access which fosters wider collaboration and increased citations

- maximum visibility for your research: over $100 \mathrm{M}$ website views per year

At $\mathrm{BMC}$, research is always in progress.

Learn more biomedcentral.com/submissions 